\title{
SYNTHESIS OF MYCOPHENOLIC ACID $\beta$-D-GLUCURONIDE AND ITS ANTITUMOR ACTIVITY
}

\author{
Kunio Ando, Seikichr Suzuki and Masahiko Arita \\ Research Laboratories, Chugai Pharmaceutical Co., Ltd., \\ Toshima-ku, Tokyo, Japan
}

(Received for pulication June 4, 1970)

\begin{abstract}
Mycophenolic acid $\beta$-D-glucuronide [V] wsa synthesized by KoENIG's KNORR reaction from methyl mycophenolate [II] and methyl-(tri-O-acetyl- $\alpha-\mathrm{D}-$ glucopyranosyl bromide)-uronate [VII]. Hydrolysis of mycophenolic acid $\beta-\mathrm{D}-$ glucuronide by $\beta$-glucuronidase liberates mycophenolic acid and glucuronic acid. Upon acid hydrolysis, the $\gamma$-lactone derivative is formed instead of mycophenolic acid. Mycophenolic acid $\beta$-D-glucuronide shows significant antitumor activity against the EHRLICH solid tumor, although it was without effect on nucleic acids synthesis of L-5178 Y cells and the growth of any microorganisms tested. The acute toxicity is very low; mice tolerate $2,000 \mathrm{mg} / \mathrm{kg}$ intraperitoneal injection.
\end{abstract}

Mycophenolic acid was found by Gosio ${ }^{1)}$ in 1896 in the culture filtrate of Penicillium brevi-compactum. The structure of mycophenolic acid was determined as [I] by BIRKINSHAw et al. ${ }^{2)}$ Although the antibiotic shows antimicrobial activity in vitro ${ }^{3)}$, it is ineffective in vivo in spite of the low toxicity ( $\mathrm{LD}_{50}$, mice $1,000 \mathrm{mg} / \mathrm{kg}$, i. p.).

Recently attention has been focussed on mycophenolic acid ${ }^{4)}$, since the antitumor activity against various transplantable tumors and antiviral activity in tissue culture systems were discovered independently in three laboratories ${ }^{5,6,7,8)}$.

In our screening study for antitumor and antiviral antibiotics, a culture filtrate of a soil Penicillium showed significant antiviral activity against some animal viruses without cytotoxicity. The active principle isolated was identified as mycophenolic acid $^{9)}$. Mycophenolic acid inhibited proliferation of some animal viruses in tissue culture with little cytotoxicity. The antibiotic showed remarkable antitumor activity against the EHRLICH solid tumor and immunosuppressive activity, but lacked activity against the EHrlich ascites tumor ${ }^{5,10)}$. WILliams et $a l .^{6}{ }^{6}$ and Carter et $a l .{ }^{7}$ ) independently reported that mycophenolic acid strongly inhibited the growth of various transplantable tumors of rodents and Rous sarcoma in chikens.

Our findings as well as those of the other laboratories prompted us to study new derivatives of mycophenolic acid, sine the antibiotic showed a side effect on the central nervous system. In addition, the antibiotic is a powerful cytostatic agent; $95 \%$ of DNA and RNA synthesis of L-5178 Y cells in tissue culture was inhibited in the presence of $0.05 \mathrm{mcg} / \mathrm{ml}$ without affecting protein synthesis (SUzuki et al., unpublished). However, the toxicity in vivo is not as high as expected; mice could tolerate $500 \mathrm{mg}$ / $\mathrm{kg}$ (i. v.). The contrast between in vivo and in vitro toxicities led us to postulate that 
the antibiotic was converted to a less toxic substance in vivo without loss of antitumor activity. It is well known that phenolic compounds are converted to the less toxic glucuronide in vivo, and rapidly excreted, Here we wish to report the synthesis of mycophenolic acid $\beta$-D-glucuronide and its preliminary evaluation as an antitumor agent.

The course for synthesis of the glucuronide [V] is demonstrated in Fig. 1. Either

Fig. 1. Synthesis of mycophenolic acid glucuronide

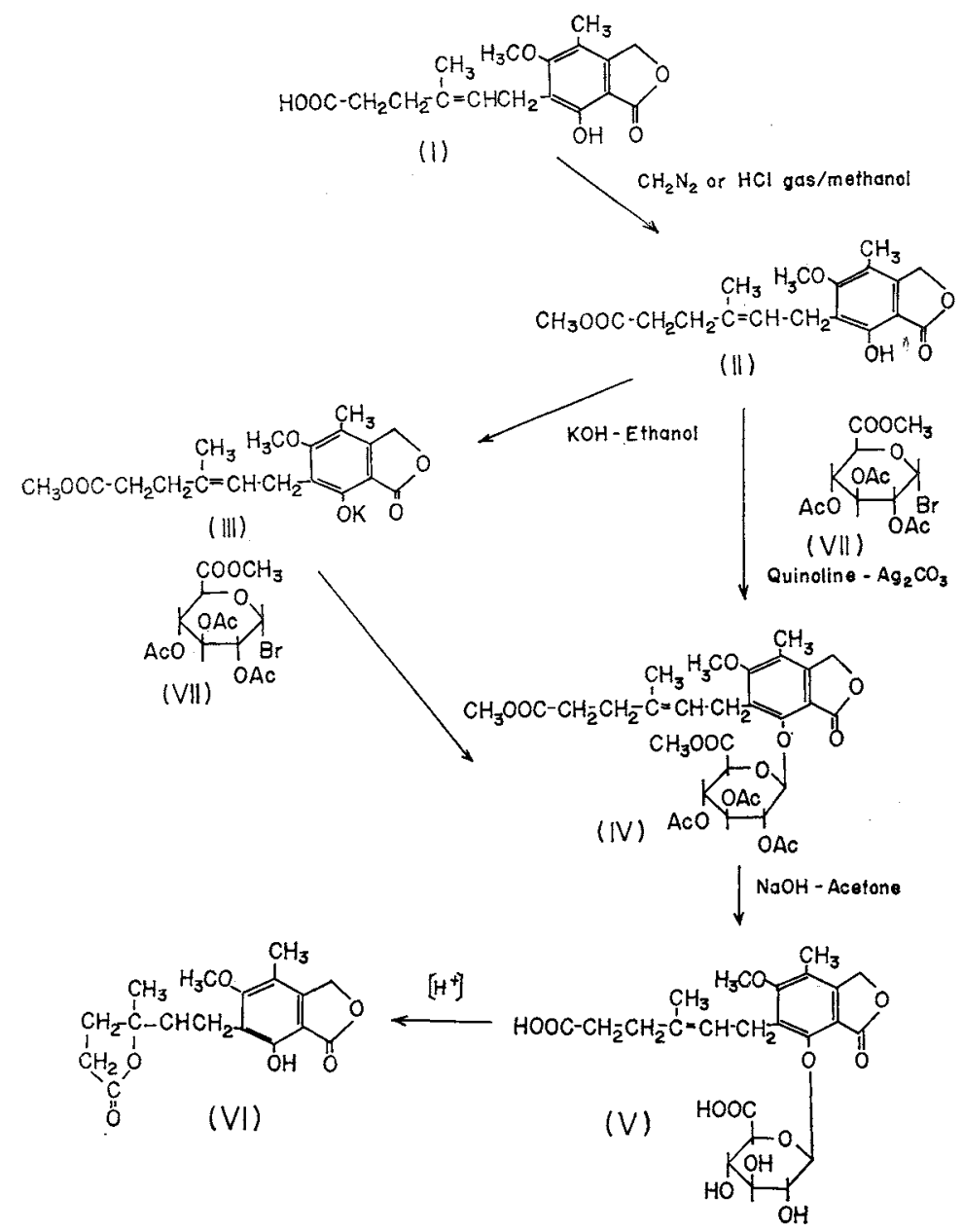

Table 1. Effect of solvents and catalyst on the condensation reaction.

\begin{tabular}{c|c|c|c|l|c|c}
\hline \multirow{2}{*}{$\begin{array}{c}\text { Experimental } \\
\text { No. }\end{array}$} & \multicolumn{2}{|c|}{ Reactants (m moles) } & Solvents and catalyst & $\begin{array}{c}\text { Reaction time } \\
\text { (hr.) }\end{array}$ & $\begin{array}{c}\text { Yields of IV } \\
\text { (\%) }\end{array}$ \\
\cline { 2 - 6 } & II & III & VII & & 72 & 23.2 \\
2 & - & 3.6 & 3.0 & Ethanol & 72 & 14.0 \\
3 & - & 3.6 & 3.0 & Acetone & 72 & 30.5 \\
4 & - & 3.6 & 3.0 & Acetone- $\mathrm{H}_{2} \mathrm{O}$ & 72 & 19.0 \\
5 & - & 2.6 & 2.0 & Acetone-Ethanol & 73 & 75.6 \\
6 & 2.1 & - & 1.5 & Quinoline- $\mathrm{Ag}_{2} \mathrm{CO}_{3}$ & 20 & 70.5 \\
\hline
\end{tabular}


methyl mycophenolate [II] or its potassium salt [III] were condensed with methyl (triO-acetyl $\alpha$-D-glucopyranosyl bromide)-uronate [VII] by KoEnIG's KNoRR reaction. The optimal conditions for the condensation were established using various solvents and reactants (Table 1). The highest yield of the condensation product, 6-[4-O-(2,3,4-triO-acetyl-methyl ester- $\beta$-D-glucopyranuronosido)-6-methoxy-7-methyl-3-oxo-5-phthalanyl]-4-methyl-4-hexenoic acid methyl ester [IV], was obtained using silver carbonate and quinoline as the solvent. When the reaction mixtures were subjected to thinlayer chromatography using toluene-ethylacetate $(2: 1)$, compound II disappeared in the reaction mixtures of Nos. 5 and 6 , whereas large amounts of II remained in the reaction mixtures of Nos. 1 4 accompanied by an unidentified product. Crystals of IV were attained using alumina column chromatography of the reaction mixture. In a preliminary test for isolation of IV from the reaction mixture, both crystalline IV and II were dissolved in benzene and the mixture was extracted with aqueous $1 \mathrm{~N}$ $\mathrm{KOH}$. Compound II was extracted into the aqueous phase. Evaporation of the benzene layer in vacuo resulted in recovery of IV in crystalline form. Subsequently IV has been isolated by this procedure without column chromatography.

Saponification and deacetylation of IV were carried out in acetone by the addition of aqueous $1 \mathrm{~N} \mathrm{KOH}$ and holding the solution at room temperature. Thus, mycophenolic acid $\beta$-D-glucuronide was obtained as needle shaped crystals.

The structure of $\mathrm{V}$ was confirmed by infrared absorption (Figs. 2 and 3) spectra, elementary analysis and hydrolysis with $\beta$-glucuronidase. As shown in Fig. 3, 5 protons out of 7 in the multiplet signal between $\tau 4.54 \sim 5.00$ are protons attached to pyranose ring, since the shape and the chemical shift are compatible with the $\beta$ configuration of the pyranose ring. The other two protons are methylene protons of the phthalide ring.

Hydrolysis of $\mathrm{V}$ with $\beta$-glucuronidase yielded I and glucuronic acid, thus further supporting that the reaction product is mycophenolic acid $\beta$-D-glucuronide.

Upon acid hydrolysis, however, mycophenolic acid (I) was not liberated but the derivative VI was isolated. The same compound VI was obtained by heating I in acid. The IR

Fig. 2. Infrared spectrum of mycophenolic acid glucuronide

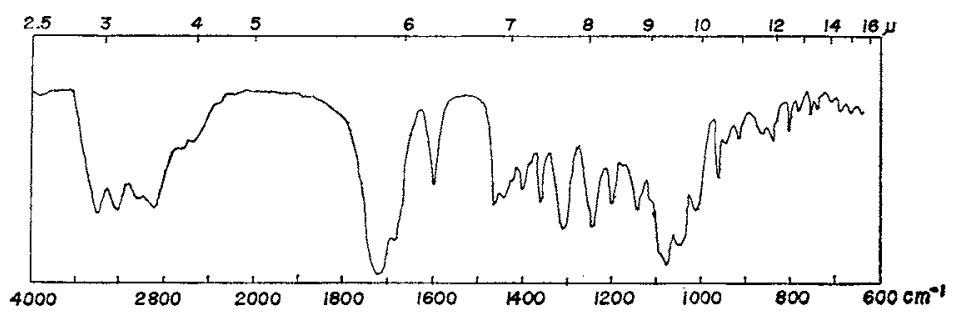

Fig. 3. NMR spectrum of mycophenolic acid glucuronide

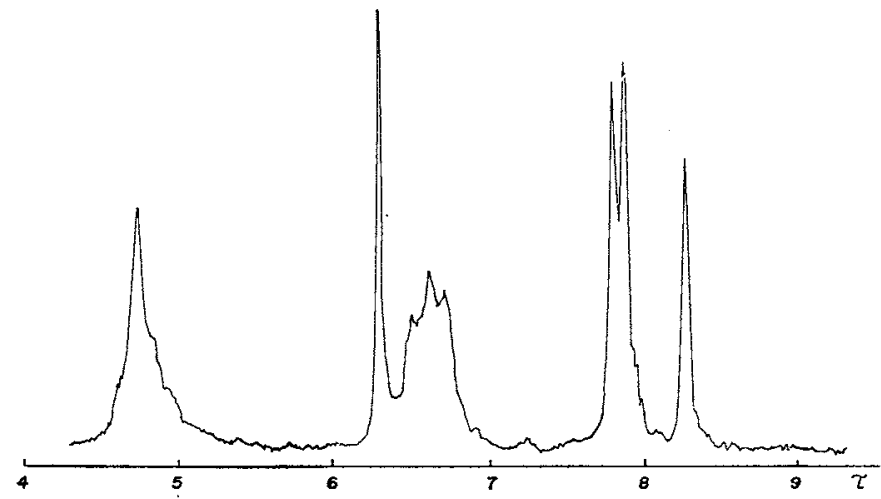


Table 2. Effect of mycophenolic acid $\beta-D$-glucuronide on EHRLICH solid carcinoma.

\begin{tabular}{l|c|c|c|c}
\multicolumn{1}{c|}{ Agents } & Dose* & $\begin{array}{c}\text { body we1gnt cnange } \\
\text { (g/mouse) }\end{array}$ & $\begin{array}{c}\text { 1 umor weignt } \\
\text { (mg/mouse) }\end{array}$ & $\begin{array}{c}\text { I umar innibition } \\
\text { rate** }\end{array}$ \\
\hline Mycophenolic acid $\beta$-D-glucuronide & 6 & 7.8 & 164 & 76.8 \\
Mycophenolic acid & 6 & 5.7 & 103 & 85.1 \\
Untreated control & - & 8.5 & 708 & 0.0 \\
\hline
\end{tabular}

* mg/mouse/day. ** Tumor inhibition rates were expressed as follows; 100-mean tumor weight of the treated group/mean tumor weight of the untreated control group.

EHRLICH ascites tumor cells $\left(4 \times 10^{\circ}\right.$ cells/mouse) were subcutaneously implanted at a left groin of the mouse of 5 weeks old, weighing $20 \sim 23 \mathrm{~g}$. The mouse used was a male Swiss albino strain ddY. The treatment was initiated 24 hours after implantation, the agents being given three times once two days. All mice were sacrificed 10 days after implantation. The solid tumor was carefully dissected out and weighed. The wet tumor weight of the treated group was compared with that of the untreated control group. Mycophenolic acid was used as a positive control agent. Twenty mice were used in each group.

spectrum indicated the presence of a new lactone ring accompanied with disappearence of a broad band at $2,500 \sim 3,000 \mathrm{~cm}^{-1}$ that was due to the carboxyl group. The presence of the phthalide group was evident from comparison of the NMR spectrum of VI with that of I. Thus, the structure was confirmed as indicated in Fig. 1.

Antitumor activity of $\mathrm{V}$ was determined using the EHRich solid tumor. As shown in Table 2, the activity of $\mathrm{V}$ equaled that of $\mathrm{I}$. Compound $\mathrm{V}$ is less toxic than $\mathrm{I}$; mice could tolerate $2,000 \mathrm{mg} / \mathrm{kg}$ (i.p.). It is also advantageous that $\mathrm{V}$ is more soluble in water than I due to introduction of the glucuronic acid moiety in the molecule.

Although $\mathrm{V}$ is active against the EHRLICH solid tumor, it is interesting that $\mathrm{V}$ shows neither antimicrobial activity nor effect on the macromolecule syntheses of L$5178 \mathrm{Y}$ cells (SuzukI et al., unpublished), whereas I possesses a broad antimicrobial spectrum and strongly inhibits nucleic acid syntheses of the cells at low concentrations without affecting protein synthesis.

FRANKLIN et al. reported the mode of action of ${ }^{11)}$. They claimed that the growth of the tumor cells was inhibited due to deficient supply of guanosine monophosphate (GMP) caused by blockade of inosine monophosphate dehydrogenase by I. This idea was supported by the facts that either the growth inhibition of tissue culture cells or antiviral activity by I were reversed by guanine, guanosine and GMP $^{12)}$.

However, the antitumor activity of I against tne EHrLICH solid tumor could not be reversed by simultaneous administration of GMP at a dose of $2 \mathrm{mg} / \mathrm{mouse}$ (ANDO, unpublished). In addition to ineffectiveness of GMP, difference in the antitumor activity of I between the EHRLICH solid and ascites carcinoma and ineffectiveness of $\mathrm{V}$ on the macromolecule syntheses of L-5178 Y cells suggest that another mode of action participates in the antitumor activity of $\mathrm{I}$ and $\mathrm{V}$ (ANDo, unpublished).

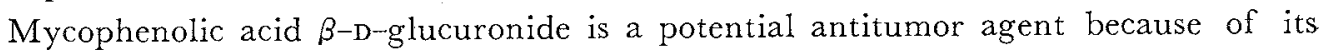
significant antitumor activity and low toxicity. The studies on the biological properties and the mode of action are now under way and the results will be presented elsewhere.

\section{Experimental}

Synthesis of methyl mycophenolate (6-(4-hydroxy-6-methoxy-7-methyl-3-oxo-5-phthalanyl)-4-methyl-4-hexenoic acid methyl ester) [II]

Procedure A) Mycophenolic acid [I] (0.5 g) was dissolved in ethanol (40 ml). Diazo- 
methane was introduced into the reaction mixture and II $(0.45 \mathrm{~g})$ was obtained as crystalline rods by recrystallization from ethanol, m.p. $105.5 \sim 106.5^{\circ} \mathrm{C}$. Calcd. for $\mathrm{C}_{18} \mathrm{H}_{22} \mathrm{O}_{6}, \mathrm{C} 64.66 \%$, $\mathrm{H} 6.63 \%$. Found, $\mathrm{C} 64.85 \%, \mathrm{H} 6.78 \%$. The methyl ester is readily soluble in benzene, chloroform and ethylacetate.

Procedure B) I $(20 \mathrm{~g})$ was suspended in methanol $(150 \mathrm{ml})$ and with vigorous stirring dry hydrogen chloride gas was introduced into it for 10 minutes. After kept standing for 2 hours in ice bath, the crude II $(19.8 \mathrm{~g})$ crystallized. Crude II was recrystallized from hot ethanol yielding purified II $(18.5 \mathrm{~g})$, yield $89 \%$, m.p. $105.5 \sim 106.5^{\circ} \mathrm{C}$. The IR spectrum was identical with that of II obtained by procedure A.

Synthesis of potassium salt of mycophenolic acid methyl ester (III)

II $(4 \mathrm{~g})$ was suspended in ethanol $(200 \mathrm{ml})$. The suspension was cooled with ice under vigorous stirring and ethanolic $\mathrm{KOH}(1.6 \%, 40 \mathrm{ml})$ was added drop by drop to the suspension. It took 20 minutes to complete the addition. Then the mixture was cooled at $-20^{\circ} \mathrm{C}$ for 16 hours. Crude III crystallized as fine needles, yield $3.8 \mathrm{~g}$. The crude III was recrystallized from hot aqueous ethanol $(100 \mathrm{ml})$ yielding purified III as needles $(3.2 \mathrm{~g})$, m.p. $175 \sim 176^{\circ} \mathrm{C}$, soluble in water. II was recovered from the aqueous solution of III by adding Amberlite IR-120 ( $\mathrm{H}^{+}$form).

Synthesis of 6-[4-O-(2,3,4-tri-O-acetyl-methyl ester- $\beta$-D-glucopyranuronosido)-6-methoxy-7-methyl-3-oxo-5-phthalanyl]-4-methyl-4-hexenoic acid methyl ester (IV)

II $(24.5 \mathrm{~g}, 73.4 \mathrm{~m}$ mole) was dissolved in quinoline $(300 \mathrm{ml})$ and then silver carbonate $(10.5 \mathrm{~g})$ was added. The reaction mixture was stirred at room temperature for 20 minutes in the dark. VII ( $21 \mathrm{~g}, 53 \mathrm{~m}$ mole) was added to the reaction mixture and stirring continued for additional 3 hours. During the reaction the mixture darkened gradually and thereafter fine crystalline needles appeared in it. Then, benzene $(300 \mathrm{ml})$ was added to dissolve the crystals and the reaction mixture was filtered with Celite. The filtrate was subsequently washed with aqueous $3 \mathrm{~N} \mathrm{HCl}(200 \mathrm{ml} \times 2)$, aqueous $1 \mathrm{~N} \mathrm{KOH}(300 \mathrm{ml} \times 2)$ and finally with water $(200 \mathrm{ml} \times 2)$. The washed filtrate was dehydrate with $\mathrm{Na}_{2} \mathrm{SO}_{4}$, decolorized with active charcoal and filtered. Concentration of the filtrate in vacuo yielded crude crystalline IV $(26.5 \mathrm{~g})$ as needles. The crude IV was recrystallized from hot ethanol yielding pure crystalline IV $(24.5 \mathrm{~g})$, m.p. $129 \sim 130^{\circ} \mathrm{C}$, yield $71.4 \%$.

Synthesis of 6 -[4-O- $(\beta-\mathrm{D}-$ glucopyrnuronosido $)-6$-methoxy-7-methyl-3-oxo-5-phthalanyl]-4-methyl-4-hexenoic acid (V)

IV $(20 \mathrm{~g})$ was dissolved in acetone $(200 \mathrm{ml})$. Aqueous $1 \mathrm{~N} \mathrm{NaOH}(200 \mathrm{ml})$ was added to the solution under cooling with tap water. After 15 minutes, Amberlite IR-120 ( $\mathrm{H}^{+}$form) was added to remove sodium ion and the filtrate obtained was concentrated in vacuo to small volume. The residue was twice washed with hot benzene $(100 \mathrm{ml} \times 2)$ and the residue was dissolved in ethanol $(100 \mathrm{ml})$ followed by the addition of petroleum ether $(50 \mathrm{ml})$. The mixture was kept standing at $-20^{\circ} \mathrm{C}$ overnight yielding crude crystalline $\mathrm{V}(13.7 \mathrm{~g})$. The crude $\mathrm{V}$ was recrystallized from ethanol - petroleum ether mixture, yield $12.3 \mathrm{~g}$, yield $80 \%$. $[\alpha]_{\mathrm{D}}^{20}-64.2^{\circ}\left(c 0.264, \mathrm{H}_{2} \mathrm{O}\right)$. Calcd. for $\mathrm{C}_{23} \mathrm{H}_{28} \mathrm{O}_{12}, \mathrm{C} 55.64, \mathrm{H}$ 5.68. Found. C 55.78, H $5.66 \%$.

\section{Hydrolysis of $\mathrm{V}$ with $\beta$-glucuronidase}

After $\mathrm{V}(58 \mathrm{mg})$ was dissolved in acetate buffer $(\mathrm{pH} 4.5,20 \mathrm{ml}), \beta$-glucuronidase solution, $1 \mathrm{ml}$, (Fishman 13,000 units $/ \mathrm{ml}$ ) was added. The mixture was incubated at $37^{\circ} \mathrm{C}$ for 20 hours. I liberated crystallized by kept standing at $5^{\circ} \mathrm{C}$ overnight and was recovered by filtration. Recrystallization from ethanol yielded $25.7 \mathrm{mg}$ of $\mathrm{I}$, yield $68.7 \%$. Glucuronic acid was detected by paper chromatography using $n$-butanol-acetic acid-water $(4: 1: 5)$ and thin-layer chromatography using $n$-butanol-acetic acid-water $(4: 1: 1)$.

Acid hydrolysis of $\mathrm{V}$

$\overline{\mathrm{V}}(0.5 \mathrm{~g})$ was dissolved in aqueous $4 \mathrm{~N} \mathrm{HCl}(50 \mathrm{ml})$ and heated on steam bath under reflux for 2 hours. After cooling, crystallized material was collected, washed thoroughly 
with water and recrystallized from ethanol. Purified VI $(0.2 \mathrm{~g})$ was obtained as prisms, m.p. $160 \sim 161^{\circ} \mathrm{C}$ - VI was insoluble in water but readily soluble in chloroform, ethylacetate and benzene. Calcd. for $\mathrm{C}_{17} \mathrm{H}_{20} \mathrm{O}_{6} ; \mathrm{C} 63.73, \mathrm{H} 6.29 \%$. Found, $\mathrm{C} 63.47, \mathrm{H} 5.97 \%$.

\section{Acknowledgement}

The authors express their hearty thanks to Drs. Y. Imar and K. OxuI for their encouragement throughout this work.

\section{References}

1) Gosio, B. : Ricerche batteriologiche e chimiche sulle alterazioni del mais. Rivista Igiene Sanita Pubblica Ann. $7: 825 \sim 868,1896$

2) Birkinshaw, J. H.; H. Raistrick \& D. J. Ross : The molecular constitution of mycophenolic acid, a metabolite of Penicillium brevi-compactum Dierckx. III. Further observations on the structural formula for mycophenolic acid. Biochem. J. 50:630 634, 1952

3) Noto, T.; M. SAWADA, K. ANDO \& K. KoYAMA : Some biological properties of mycophenolic acid. J. Antibiotics $22: 165 \sim 169,1969$

4) Noto, T.; Y. HARADA \& K. KoYAMA : A turbidimetric bioassay method for determination of mycophenolic acid. J. Antibiotics $23: 96 \sim 98,1970$

5) Suzuki, S.; T. Kimura, K. Ando, M. Sawada \& G. Tamura : Antitumor activity of mycophenolic acid. J. Antibiotics $22: 297 \sim 302,1969$

6) Williams, R. H.; D. H. Lively, D. C. Delong, J. C. Cline, M. J. Sweeney, G. A. Poore \& S. H. LARSEN : Mycophenolic acid: Antiviral and antitumor properties. J. Antibiotics $21: 463 \sim 464$, 1968

7) Carter, S. B.; T. J. Franklin, D. F. Jones, B. J. Leonard, S. D. Millus, R. W. Turner \& W. B. Turner: Mycophenolic acid: An anti-cancer compound with unusual properties. Nature $223: 848 \sim 850,1969$

8) SweEney, M. J.; J. C. Chine \& R. H. Wiluiams: Antitumor and antiviral activities of mycophenolic acid. Proc. Am. Assoc. Cancer Res. 10:90, 1969

9) Tamura, G.; K. Ando, S. Suzuki, A. Takatsukt \& K. Artma: Screening of antiviral antibiotics by paper disc agar diffusion plaque inhibition method. Abstracts papers of Ann. Meet. Agri. Chem. Soc. Japan, pp. 258 259, 1968.

Ando, K.; S. Suzuki, G. Tamura \& K. Arima : Antiviral activity of mycophenolic acid. J. Antibiotics $21: 649-652,1968$

10) Mrrsui, A. \& S. Suzuki : Immunosuppressive effect of mycophenolic acid. J. Antibiotics 22 : 358 363,1969

11) FRANKLIN, T. J. \& J. M. COOK: The inhibition of nucleic acid synthesis by mycophenolic acid. Biochem. J. $113: 515 \sim 524,1969$.

12) Cline, J. C.; J. D. Nelson, K. Gerzon, R. H. Williams \& D. C. DeLong : In vitro antiviral activity of mycophenolic acid and its reversal by guanine type compounds. Appl. Microbiol. 18 : 14 20, 1969 